\title{
ANALISIS PROFITABILITAS PADA PT. BANK PEMBANGUNAN DAERAH SUMATERA BARAT
}

\author{
Siti Rohayati, Jhon Fernos \\ Akademi Keuangan Perbankan "Pembangunan" Padang \\ Jhonfernos@akbpstie.ac.id
}

\begin{abstract}
The company's ability to generate net income in 2012 and 2014 does not include BI's efficient standards because of the low value of NPM due to higher sales or costs. The net profit earned from the company's operations with the amount of assets used to generate profits is not efficient because the value is lower than the BI standard because the amount of assets is greater than the profit obtained.The company's ability to generate profits from operating return on capital in 2013 was very efficient because the value of ROE in 2013 was above the standard of Bank Indonesia.
\end{abstract}

Keywords: Bank, Rentability Ratio

\section{PENDAHULUAN}

Laporan keuangan merupakan data-data keuangan yang sifatnya kuantitatif. Menurut Harahap (2009:105) laporan keuangan menggambarkan kondisi keuangan dan hasil usaha suatu perusahaan pada saat tertentu atau jangka waktu tertentu. Adapun jenis laporan keuangan yang lazim dikenal adalah neraca, laporan laba rugi atau hasil usaha, laporan perubahan ekuitas, laporan arus kas, laporan posisi keuangan. Untuk memperoleh perkembangan atau kinerja kegiatan usaha suatu bank perlu diadakan suatu interpretasi atau analisa terhadap finansial bank yang bersangkutan.

Bagi perusahaan umumnya mempunyai tujuan paling utama adalah mendapatkan keutungan yang optimal. Meskipun demikian, masalah profitabilitas adalah lebih penting dari ada masalah laba, karena laba yang besar saja belumlah merupakan ukuran bagi perusahaan tersebut telah bekerja dengan efisien. Efisien baru dapat diketahui dengan membandingkan laba usaha perusahaan tersebut atau dengan kata lain adalah menghitung profitabilitasnya.

Menurut Sutrisno (2009:222), "Profitabilitas adalah hasil dari kebijaksanaan yang diambil oleh manajemen. Rasio keuangan untuk mengukur seberapa besar tingkat keuntungan menunjukkan semakin baik manajemen dalam mengelola perusahaan".

Berdasarkan pernyataan tersebut, profitabilitas suatu bank dapat diukur dengan beberapa ratio-ratio keuangan, yaitu : Return on Assets, Return on Equity, Biaya Operasional (BOPO) dan Net Profit Margin.

Menurut Sawir (2009:20) Return on Equity adalah rasio yang memperlihatkan sejauh manakah perusahaan pengelola modal sendiri secara efektif, mengukur tingkat keuntungan dari intervensi yang telah dilakukan pemilik modal sendiri atau pemegang saham perusahaan. Semakin tinggi rasio ini semakin tinggi keuntungan investor karena semakin efisien modal yang ditanamkan. Rasio ini digunakan untuk mengukur kemampuan modal sendiri untuk menghasilkan keuntungan bagi seluruh pemegang saham, baik saham biasa maupun saham preferen. 
Biaya Operasional (BOPO) adalah perbandingan antara biaya operasional dan pendapatan operasional. Rasio biaya operasional digunakan untuk mengukur tingkat efisien dan kemampuan bank dalam melakukan kegiatan operasinya.

Menurut Dwi Pastowo (2005:97) rasio Net Profit Margin (NPM) merupakan rasio yang mengukur rupiah laba yang dihasilkan oleh setiap satu rupiah penjualan.

Tabel 1

Perkembangan Profitabilitas PT. BPD Sumatera Barat

Tahun $2013-2015$

\begin{tabular}{llll}
\hline Keterangan & \multicolumn{1}{c}{2013} & \multicolumn{1}{c}{2014} & \multicolumn{1}{c}{2015} \\
\hline Return On Assets & $2,65 \%$ & $1,93 \%$ & $2,29 \%$ \\
Return On Equity & $15,63 \%$ & $14,96 \%$ & $15,86 \%$ \\
BOPO & $248,115 \%$ & $164,87 \%$ & $137,01 \%$ \\
\hline
\end{tabular}

Sumber : data olahan

Berdasarkan tabel 1 diatas dapat dilihat bahwa PT BPD Sumatera Barat dalam hal ini neraca dan laporan laba rugi perusahaannya dalam posisi profitabilitas masih berfluktuasi. Hal ini dapat dilihat pada tahun 2013 ROA (2,65 \%) sedangkan tahun 2014 ROA $(1,93 \%)$ mengalami penurunan $(1,37 \%)$ sedangkan pada tahun 2015 ROA $(2,29 \%)$ mengalami kenaikan sebesar 0. $36 \%$, Tahun 2013 ROE $(15,63 \%)$ sedangkan tahun 2014 ROE (14.96\%) megalami penurunan sebesar $0.67 \%$ sedangkan tahun 2015 ROE $(15,86)$ mengalami kenaikan sebesar 0.9. Tahun 2013 BOPO $(248,115 \%)$ sedangkan tahun 2014 (164.87) mengalami penurunan sebesar 83,245 \% sedangkan Tahun 2015 BOPO 137, $01 \%$ mengelami penurunan sebesar 2,876 \%.

Sesuai dengan latar belakang masalah, peulis membuat perumusan sebagai berikut : Bagaimana Tingkat Profitabilitas pada PT. BPD Sumatera Barat.

\section{LANDASAN TEORI \\ Pengertian Bank}

Bank adalah lembaga keuangan yang menghimpun dana dari masyarakat dan kemudian menyalurkannya dalam bentuk kredit dan atau bentuk-bentuk lainya, dalam rangka untuk meningkatkan taraf hidup rakyat banyak.

Menurut UU No. 10 Tahun 1998 Bank Konvensional adalah bank yang melaksanakan kegiatan usaha secara konvensional yang dalam kegiatannya memberikan jasa dalam lalulintas pembayaran.

\section{Pengertian Bank Konvensional}

Bank Konvensional adalah bank melaksanakan kegiayan usaha secara konvensional, yang dalam kegiatannya memberikan jasa dalam lalulintas pembayaran secara umum berdasarkan prosedur dan ketentuan yang telah ditetapkan.

Fungsi bank

1. Penghimpun dana

2. Penyalur dana-dana yang terkumpul oleh bank disalurkan kepada masyarakat dalam bentuk pemberian kredit, pembelian surat-surat berharga, penyertaan, pemilikan harta tetap.

3. Pelayanan jasa bank dalam mengemban tugas sebagai pelayanan lalulintas pelayanan uang melakukan berbagai aktifitas kegiatan antara lain pengiriman uang, inkaso, cek wisata, kartu kredit dan pelayanan lainnya. 


\section{Pengertian dan Tujuan Analisis Laporan Keuangan}

Pengertian dan analisis Laporan Keuangan setelah laporan keuangan disusun berdasarkan data yang relevan, serta dilakukan dengan prosedur akutansi dan penilaian yang benar, akan terlihat kondisi keuangan perusahaan yang sesungguhnya.

\section{Tujuan dan Analisis Laporan Keuangan}

1. Untuk mengetahui posisi keuangan perusahaan dalam satu periode tertentu

2. Untuk mengetahui kelemahan-kelemahan apa saja yang menjadi kekurangan perusahaan.

3. Untuk mengetahui kekuatan-kekuatan yang dimiliki.

4. Untuk mengetahui langkah-langkah perbaikan apa saja yang perlu dilakukan kedepan yang berkaitan dengan posisi keuangan perusahaan saat ini.

5. Untuk melakukan penilaian kinerja manajemen kedepan perlu penyegaran atau tidak karena sudah dianggap berasil atau gagal.

\section{Rasio Profitabilitas}

Rasio yang menunjukan besarnya laba yang diperoleh sebuah perusahaan dalam periode tertentu.Rasio ini digunakan untuk menilai seberapa efisien pengelola perusahaan dapat mencari keuntungan atau laba untuk setiap penjualan yang dilakukan.

\section{Pengertian Profitabilitas}

Menurut munawir (2007:240) profitabilitas adalah rasio yang digunakan untuk menilai kemampuan perusahaan untuk memperoleh keuntungan.

Profitabilitas adalah jumlah yang berasal dari pengurangan harga pokok produksi, biaya lain dan kerugian dari penghasilan atau penghasilan operasi. Profitabilitas merupakan ukuran pokok keseluruhan keberhasilan suatu perusahaan (Simamora 2000:528)

\section{Profitabilitas Berdasarkan Jenis Produk}

Analisis kemampuan menghasilkan laba dapat diterapkan pada jenis produk. analisis ini ditujukan untuk mendeteksi penyebab timbulnya laba atau rugi yang dihasilkan oleh satiap jenis produk dalam periode akuntan tertentu (Mulyadi,2001:58) dalam menganalisis profitabilitas setiap jenis produk dapat digunakan dua konsep biaya sebagai berikut :

1. Konsep harga pokok ( fuul costing )

2. Konsep harga pokok Variabel( Variable costing)

\section{Tujuan Dan Manfaat Rasio Profitabilitas}

Manfaat rasio profitabilitas tidak terbatas hanya pada pemilik usaha atau manajemen saja, tetapi juga baik bagi pihak luar perusahaan, terutama pihak-pihak yang memiliki hubungan atau kepentingan dengan perusahaan.

Tujuannya adalah agar terlihat perkembangan posisi keuangan perusahaan dalam rentang waktu tertentu, baik penurunan atau kenaikan, sekaligus sebagai evaluasi terhadap kinerja manajemen sehingga dapat diketahui penyebab dari perubahan kondisi keuangan perusahaan tersebut. semakin lengkap jenis rasio yang digunakan, semakin sempurna hasil yang akan dicapai, sehingga posisi dan kondisi tingkat profitabilitas perusahaan dapat diketahui secara sempurna.

\section{Faktor-faktor yang Mempengaruhi Profitabilitas}

Manajemen adalah merupakan factor utama yang mempengaruhi profitabilitas bank, besar kecilnya bank dan lokasi bank bukan merupakan faktor yang paling menentukan. Akan tetapi manajemen yang baik yang ditunjang oleh faktor modal dan kombinasi ideal untuk keberhasilan bank. 
Dari segi manajemen ada tiga aspek yang penting diperhatikan, yaitu Balance sheete management, operating management dan Financial management.

Operating management sebagai aspek kedua merupakan manjemen bank yang berperan dalam menaikkan profitabilitas dengan cara menekan biaya .sebagaimana disebutkan diatas, biaya adalah salah satu factor yang ikut menentukan tinggi rendahnya profitabilitas .jadi,tidak cukup hanya menaikkan pendapatan bruto saja ,akan tetapi juga harus berusaha menaikkan efisiensi pengguaan biaya dan menaikkan produktivitas kerja.yang juga termasuk dalam operating management adalah usaha untuk menekan cost of money.menekan tingkat biaya sampai pada suatu titik yang yang paling efisien bagi bank adalah suatu proses yang terus- menerus, tidak bisa sekali jadi melalui rumus -rumus .

\section{METODE PENELITIAN}

Dalam pengumpulan data dan bahan untuk penelitian ini digunakan metode penelitian sebagai berikut :

1. Metode Pengumpulan Data

a. Studi Lapangan

Peninjauan langsung ke objek penelitian yang dipilih untuk meneliti hasil data sekunder. Penelitian langsung kelapangan ini akan dapat membantu penulis untuk melengkapi data yang diperlukan. Adapun cara riset lapangan ini adalah dengan mewawancarai langsung pihak-pihak yang berkepentingan dalam hal in iadalah perusahaan dan instansi yang terkait.

b. Studi Kepustakaan (Library Research)

Penelitian yang dilakukan keperpustakaan beberapa buku-buku ilmiah dan tulisan-tulisan yang berhubungan dengan pembahasan yang dilakukan.

2. Metode Analisa Data

Dalam menganalisa data menggunakan analisa data kualitatif dan kuantitatif. Dimana metode kualitatif menggambarkan, memahami dan menjelaskan data yang diteliti selama penelitian berlangsung. Sedangkan metode kuantitatif menganalisa perhitungan tingkat profitabilitas pada PT. BPD Sumatera Barat.

\section{HASIL DAN PEMBAHASAN}

Return on assets menunjukkan kemempuan suatu perusahaan menghasilkan laba dari aktiva yang dipergunakan.semakin tinggi rasio ini merupakan efektifitas dalam menggunakan total aktiva dalam menghasilkan laba .Dalam kerangka penilaian kesehatan bank, BI akan memberikan score maksimal 100 (sehat) apabila bank memiliki ROA lebih dari 1,5\%.

1. Return On Equity (ROE)

Return On Equity menunjukan dari modal sendiri untuk menghasilkan keuntungan bagi pemegang saham preferen dan saham biasa, semakin besar Rasio ini maka semakin baik. Bahwa Return On Equity merupakan rasio yang mengukur kemampuan suatu perusahaan dalam menghasilkan laba bersih dari modal sendiri yang digunakan oleh perusahaan. Menurut standar BI ROE adalah lebih dari $12 \%$ (Baik).

2. Biaya Operasional Terhadap Pendapatan Operasional (BOPO)

Rasio BOPO digunakan untuk mengukur perbandingan antara biaya operasinal yang ditanggung bank apabila dibandingkan dengan pendapatan operasional yang mampu dihasilkan. Semakin tinggi persentase BOPO menunjukan biaya 
operasional yang terjadi melebihi pendapatan operasional yang mampu diperoleh oleh suatu bank.menurut standar BI menetapkan rasio BOPO adalah dibawah $90 \%$, karena jika rasio BOPO melebihi $90 \%$ hingga mendekati $100 \%$ maka bank tersebut dapat dikategorikan tidak efisien dalam menjalan operasionalnya.

\section{Pembahasan}

1. Return On Assets (ROA)

$$
\text { ROA }=\frac{\text { laba sebelum pajak }}{\text { Total Aktiva }} \times 100 \%
$$

Tabel 2

Perhitungan Return On Assets PT. BPD Sumatera Barat

Tahun 2013 - 2015

( Dalam Ribuan Rp )

\begin{tabular}{cccc}
\hline Tahun & $\begin{array}{c}\text { Laba Sebelum Pajak } \\
(1)\end{array}$ & $\begin{array}{c}\text { Total Aktiva } \\
(2)\end{array}$ & $\begin{array}{c}\text { Return On Asset (ROA) } \\
(1: 2) \times 100 \%\end{array}$ \\
\hline 2013 & 431.321 & 16.244 .113 & 2.65 \\
2014 & 348.247 & 18.014 .579 & 1.93 \\
2015 & 446.825 & 19.448 .300 & 2.29
\end{tabular}

Sumber : Data Olahan

Dari tabel 3.1 diatas nilai ROA Pada Tahun 2013 sebesar $2.65 \%$ tahun 2014 $1.93 \%$ dan tahun 2015 sebesar $2.29 \%$

\section{Return On Equity (ROE)}

3.

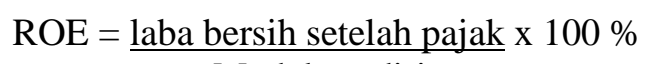

Modal sendiri

Tabel 3.

Perhitungan Return On Equity PT. BPD Sumatera Barat

Tahun 2013 - 2015

( Dalam Ribuan Rp )

\begin{tabular}{cccc}
\hline Tahun & $\begin{array}{c}\text { Laba Bersih Setelah Pajak } \\
(1)\end{array}$ & $\begin{array}{c}\text { Modal sendiri } \\
(2)\end{array}$ & $\begin{array}{c}\text { Return On Equity (ROE) } \\
(1: 2) \times 100 \%\end{array}$ \\
\hline 2013 & 312.725 & 2.000 .000 & 15.63 \\
2014 & 293.793 & 2.000 .000 & 14.69 \\
2015 & 317.279 & 2.000 .000 & 15.86 \\
\hline
\end{tabular}

Sumber : Data Olahan

Dari tabel 3.2 diatas nilai ROE Pada Tahun 2013 sebesar $15.63 \%$ tahun 2014

$14.69 \%$ dan tahun 2015 sebesar $15.86 \%$

4. Biaya Operasional terhadap pendapatan Operasional (BOPO)

$$
\mathrm{BOPO}=\frac{\text { Beban Opersional }}{\text { Pendapatan Operasional }} \times 100 \%
$$

Tabel 4

Perhitungan Biaya Operasional terhadap Pendapatan Operasional PT. BPD Sumatera Barat Tahun 2013 - 2015 ( Dalam Ribuan Rp )

\begin{tabular}{cccc}
\hline Tahun & $\begin{array}{c}\text { Beban Operasional } \\
(1)\end{array}$ & $\begin{array}{c}\text { Pendapatan Operasional } \\
(2)\end{array}$ & $\begin{array}{c}\text { BOPO } \\
(1: 2) \times 100 \%\end{array}$ \\
\hline 2013 & 85.689 & 34.536 & 248.115 \\
2014 & 83.476 & 50.630 & 164.87 \\
2015 & 92.634 & 67.611 & 137.01 \\
\hline
\end{tabular}

Sumber : Data Olahan 
Dari tabel 3.3 diatas nilai BOPO Pada Tahun 2013 sebesar $248.115 \%$ tahun 2014 Sebesar $164.87 \%$ dan tahun 2015 sebesar $137.01 \%$.

\section{SIMPULAN}

Berdasarkan hasil analisis pada Bab sebelumnya profitabilitas PT. BPD Sumatera Barat selama periode Tahun 2013 sampai dengan Tahun 2015. Hal ini ditunjukan dengan indikator sebagai berikut :

1. Dari rasio ROA PT BPD Sumatera Barat Tahun 2013 ROA sebesar $2.65 \%$, bulan tahun 2014 nilai ROA sebesar $1.93 \%$ sedangkan tahun 2015 nilai ROA sebesar $2.29 \%$ jadi dari Bulan tahun 2013 sampai dengan tahun 2015 mengalami kenaikan. Sehingga bank mampu menghasilkan laba bersih sebelum pajak karena nilai ROA semakin baik, sehingga bank bisa beroperasi dengan efektif dan efisien dalam menggunakan atau memanfaatkan aktiva yang dimilikinya dalam menghasilkan keuntungan.

2. Dari rasio ROE PT BPD BPD Sumatera Barat pada tahun 2013 ROE sebesar $15.63 \%$, tahun 2014 nilai ROE sebesar $14.69 \%$ sedangkan tahun 2015 nilai ROE sebesar $15.86 \%$ jadi dari tahun 2013 sampai dengan tahun 2015 mengalami kenaikan. Sehingga kemampuan bank dalam mengahasilkan laba bersihnya sangat baik .

3. Dari rasio BOPO tahun 2013 nilai BOPO sebesar $248.115 \%$ tahun 2014 nilai BOPO sebesar $164.87 \%$, tahun 2015 nilai BOPO sebesar $137.01 \%$, bahwa untuk mengukur kemampuan pendapatan operasionalnya dalam menutup biaya operasional, semakin kecil BOPO semakin efisien bank tersebut mengendalikan biaya operasionalnya, maka keuntungan yang diperoleh bank akan semakin besar.

\section{DAFTAR PUSTAKA}

Afriyeni, A. Fernos, J (2018). Analisis Faktor-Faktor Penentu Kinerja Profitabilitas Bank Perkreditan Rakyat (BPR) Konvensional Di Sumatera Barat. Jurnal Benefita: Ekonomi Pembangunan Manajemen Bisnis Dan Akuntansi. Volume 3. No. 3. http://doi.org/10.22216/jbe.v3i3.3623

Arifin, I. Z., \& Marlius, D. (2017). Analisis Kinerja Keuangan PT. Pegadaian Cabang Ulak Karang. https://doi.org/10.31227/osf.io/n2peu

Bank Indonesia, 2002. Studi Ekonomi Bantuan Profitabilitas Bank Indonesia, Jakarta

Bank Indonesia, 2012. Laporan Keuangan Publikasi Bank Nagari

Fernos, J (2017). Analisis Rasio Profitabilitas Untuk Mengukur Kinerja (Studi Kasus Pada PT. Bank Pembangunan Daerah Provinsi Sumatera Barat. Jurnal Pundi. Vol 01. No 02. https://doi.org/10.31575/jp.v1i2.25

Iswari, M., \& Fernos, J. (2019). Analisis Tingkat Kesehatan Bank Pada PT. Bank Pembangunan Daerah Sumatera Barat. https://doi.org/10.31227/osf.io/ja7ty 
Jumingan. 2011. Analisis Laporan Keuangan. PT. Bumi Aksara. Jakarta

Handayani, M., \& Marlius, D. (2017). Analisis Tingkat Kesehatan PT. BPR Batang Kapas. https://doi.org/10.31227/osf.io/bq48z

Kasmir. 2002. Analisis Laporan Keuangan. PT. Raja Grafindo Persada. Jakarta

Kasmir. 2008. Manajemen Perbankan. PT. Raja Grafindo : Jakarta

Latif, F., \& Fernos, J. (2019). Analisis Rasio Profitabilitas Untuk Mengukur Kinerja Bank BPR Harau Payakumbuh. https://doi.org/10.31227/osf.io/27vqg

Munawir. 2007. Analisis Laporan Keuangan. Cetakan Ke-14. Liberty. Yogyakarta

Putri, Y. A., \& Marlius, D. (2018). Analisis Tingkat Kesehatan Bank Pada PT. Bank Perkreditan Rakyat (BPR) Jorong Kampuang Tangah Pariaman Cabang Padang. https://doi.org/10.31227/osf.io/r98pv

Rahmayeli, D. S., \& Marlius, D. (2017). Analisis Kinerja Keuangan Pada PT. Bank Perkreditan Rakyat (BPR) Batang Kapas Pesisir Selatan. https://doi.org/10.31227/osf.io/sz5db

Undang-Undang Republik Indonesia No. 10 Tahun 1998 tentang Perubahan UndangUndang No. 7 Tahun 1992 tentang Perbankan

Zahiruddin, dkk. 2012. Manajemen Perbankan. Bumi Aksara. Jakarta 